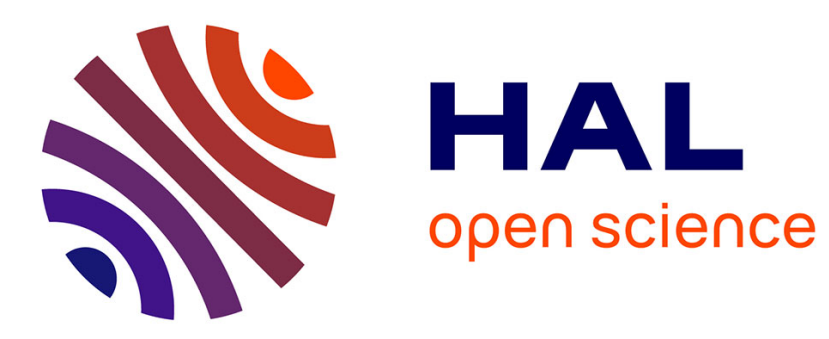

\title{
Income inequality between skilled individuals
}

Serge Svizzero, Clement Allan Tisdell

\section{To cite this version:}

Serge Svizzero, Clement Allan Tisdell. Income inequality between skilled individuals. International Journal of Social Economics, 2003, 30 (11), pp.1118-1130. 10.1108/03068290310497486 . hal02163228

\section{HAL Id: hal-02163228 \\ https://hal.univ-reunion.fr/hal-02163228}

Submitted on 24 Jun 2019

HAL is a multi-disciplinary open access archive for the deposit and dissemination of scientific research documents, whether they are published or not. The documents may come from teaching and research institutions in France or abroad, or from public or private research centers.
L'archive ouverte pluridisciplinaire HAL, est destinée au dépôt et à la diffusion de documents scientifiques de niveau recherche, publiés ou non, émanant des établissements d'enseignement et de recherche français ou étrangers, des laboratoires publics ou privés. 


\title{
Income inequality between skilled individuals
}

\author{
Serge Svizzero \\ Universite, de la Reunion, Faculte de Droit et d'Economie, \\ Saint Denis, France, and \\ Clem Tisdell
}

School of Economics, University of Queensland, Brisbane, Australia

Keywords Education, Globalization, Innovation, Labour Market

\begin{abstract}
It is widely agreed that income inequality has increased in OECD countries over the past two decades. Most of the debate has focused on the distinction between skilled and unskilled workers. However inequality increased not only among those with different observable traits but also within groups of workers with the same characteristics such as gender, race, education and experience. This poses a challenge for theories that try to explain the rise in overall earnings inequality. Indeed, is income inequality within groups explained by the same reasons that have led to income inequality between groups? It appears that some reasons are specific to inequality within groups. For instance, greater access to education has led to some confusion about the standard associated with the same educational level. Consequently, innate ability plays an increasing part in the determination of workers' rewards. Similarly, the reduction of the size of the public sector may have contributed to the rise of the variability of the demand for skills. However, the central reason - innovation, notably the introduction of new technologies - is common to both types of inequality but it acts on within-group income inequality through specific channels. Among the latter are the role of innate ability, the shift toward a decentralised wage determination system, and the changes of the demand for skills. Therefore, the explanations of within-group inequality are complementary to the ones associated with between-group inequality and thus help to explain the rise in overall earnings inequality.
\end{abstract}

\section{Introduction}

After the Second World War and until the early 1990s, few academic papers dealt with economic inequality despite some exceptions (Sen, 1973). Since the early 1990s, this is not true. As pointed out by Atkinson and Bourguignon (1998), "There was a time in the post-war period when interest in the distribution of income had almost vanished [...]. Today, the position is different”. Many studies and papers deal with income distribution and income inequality (Atkinson, 1997). This renewal of interest is explained by the fact that, since the mid-1970s and despite economic growth, wage inequality and skill differentials in earnings and employment increased sharply in OECD countries. In other words, and contrary to the prediction of Kuznets' curve (Kuznets, 1955), the recent historical experience indicates that economic growth does not always reduce inequality (Aghion and Williamson, 1998). In fact, the relation between economic growth and income inequality - namely between-skill group inequality - is quite controversial. For example, in 1979, 1987 and 1995, economic performance was similar in the USA. However, the 
Gini index of household income inequality rose in both 1979 and 1987 but fell in 1995 (US Council of Economic Advisors, 1998).

Although there is no definite trend in the degree of income inequality between groups, this is not true of within-group inequality. Indeed, Juhn et al. (1993) showed that while the educational premium fell in the 1970s and rose in the 1980s, within-group inequality has risen steadily since the early 1970s. Of course one may claim that this result is biased since the composition of "a group" changes over time. Nevertheless, Juhn et al. (1993) confirmed that no matter how narrowly groups are defined in terms of different variables (such as experience, education, gender, race, occupation, industry and so on) the increase in wage income inequality within groups does not disappear.

Moreover, the studies of wage mobility conducted by Buchinsky and Hunt (1999) and Disney (2000), respectively for the USA and the UK, reach the same conclusion. Wage mobility is a measure of the ability of workers to change jobs and then to move from one group to another during their life. It appears from both studies that wage mobility decreases when wage inequality rises. In other words, when income inequality increases, the composition of a group is more rigid and therefore the study of income inequality within that group is quite relevant.

Therefore, the study of between-group inequality and within-group inequality deserves to be treated separately. A study of the latter is quite important because as claimed by the US Council of Economic Advisors (1998) "Within-group inequality is also on the rise and in fact accounts for about two-thirds of the total increase in earnings inequality". This Council demonstrated that when grouping workers either by education level (e.g. male high school graduates) or by age (e.g. 25 to 34-year-old full-time), similar findings emerge, i.e. the 90/50 and the 50/10 earnings ratios[1] have risen since about 1970. A similar conclusion is reached by Gottschalk (1997, p. 32) who claims that “. . the increase in inequality within groups accounts for 50 percent of the total increase in inequality for men and 23 percent of the changes for females".

Until now, most studies have focused on income inequality between-groups, more specifically on inequality between unskilled workers and skilled employees. Three main alternative explanations for the observed increase in earnings inequality between-groups have been given.

(1) Supply-side factors can increase inequality if, for instance, the increase of unskilled labor supply is considerable. The main factors in several OECD countries are, on the one hand the increasing numbers of immigrants in the labor market (specially at low income levels) (Borjas, 1994), and on the other hand the increasing labor force participation rates of women who tend to have less work experience than males.

(2) On the demand-side, the increase of inequality may stem from the reduction of the demand for unskilled workers and the rise of the 
demand for skilled employees. In the literature, both phenomena are often explained either by economic globalisation, namely increased trade between North and South (where the abundant factor is unskilled labor) countries (Wood, 1998) or by skilled-biased technological change (Lawrence and Slaughter, 1993). The latter view is the dominant explanation. However, as pointed out by Svizzero and Tisdell (2001), both explanations are closely related.

(3) The third explanation - in fact a set of explanations - suggests that changes in institutional arrangements in the labor market, such as declining influence of unions, has led to lower returns for unskilled workers. Nevertheless, even this could be in the final analysis a consequence of both globalisation and technological change.

It is interesting to consider to what extent the above mentioned three explanations for growing income inequality between groups explain expanding income inequality within groups. If they are able to explain only a part of the within-group inequality, some additional explanations must be provided.

The paper is organized as follows: factors leading to variations of the demand for skills are outlined in Section 2. Supply-side factors and the influence of changes in wage-setting institutions are studied in Section 3. Section 4 is devoted to examining innate ability and its influence on income levels. The role of the education system in influencing income inequality is investigated and discussed critically in Section 5.

\section{Variations in the demand for skills}

It appears that the demand for skills is quite variable over time. Possibly the main reason for this variability is innovation. Indeed, innovation involves a new or modified product (this is product innovation) a new or modified way of making a product (this is process innovation), and sometimes it consists of a new or modified method of business organization. Innovation may be stimulated by demand factors such as altering sociological factors, for instance changing tastes of consumers (e.g. today people take more care about their health). It may also be partly supply-driven by technical factors, i.e. through the emergence of inventions (such as those associated with the IT revolution). In both cases, the demand for skills evolves and changes, i.e. some skills that were in excess demand early in the innovation cycle become in excess supply in the latter part of the cycle. This is consistent with each skill or level of education. Moreover, when technological change occurs, this gives rise to a process akin to the "product life cycle". After a while, an increasingly part of the innovation is embodied in products and machines. Therefore, some skills that were excessively demanded initially are less demanded. This also contributes to the volatility of the demand for skills. Depending on tastes and technology - both 
factors being quite difficult to forecast - the demand for skills a few years into the future is very unpredictable.

As pointed out by Lindbeck and Snower (1996), the organization of many firms in both the manufacturing and service sectors has been progressively restructured over recent years as a result of innovation. The restructuring process is characterized by a shift from Tayloristic organizations to holistic ones. In the former, workers are assigned to a specific task, i.e. the organization is based on the specialization of work. In the latter, as a result of the increasing use of computers and the rising versatility and programmability of equipment, the complementarities across tasks that a given worker can exploit has risen. This process induces the need for extreme specialization by skill-specific occupation, creates demands for new combination of skills and thereby leads to new patterns of wage inequality.

The link that exists in Tayloristic organizations between the distribution of wages and the distribution of productivities is broken in holistic organizations. Indeed, in the latter case where individual workers are assigned multiple tasks, the distribution of task productivities no longer coincides with the distribution of productivities across people. Therefore, this process which increases the demand for versatility "resegments" the labour market. Inequality in wages and job opportunities depend less on workers' productivities at specific task occupations and more on their degree of versatility across tasks. The fact that people within given occupational, educational, and job tenure groups differ substantially in terms of their versatility, as well as the social and cognitive skills necessary for success in holistic organizations, helps to explain the widening wage dispersion within these occupational, educational, and job tenure groups.

Another explanation of changes in the composition of demand for skills is provided by the recent reduction in most OECD countries of the size of the public sector (see Table I). This reduction derives from economic globalisation, structural adjustment policies, and more generally from the shift towards a market economy that started in the late 1970s in the USA and the UK. This reduction has several implications for income inequality within the skilled group. The public demand for labor has globally decreased but, more importantly, its components have changed. Some specific skills are no longer demanded since some public activities have been privatized. Some new skills are now demanded by the public sector because in some economic activities the public sector is now competing with the private one. More generally, there are disciplines (such as history, arts) that might have been demanded in the public service. Today, the public sector tries to be more efficient, more competitive and therefore seems to demand people having skills related to business. Others - those specialized in topics such as arts or history - find it more difficult to get a job, i.e. despite their level of education, because their skills are in little demand by the private sector as well as by the public sector. There appears to 
Table I.

Share of the public employment over total employment (per cent)

\begin{tabular}{lrrrrr}
\hline & 1985 & 1990 & 1997 & 1998 & 1999 \\
\hline Canada & 20.2 & 20.3 & 18.5 & 17.9 & 17.5 \\
Finland & 25.3 & 23.2 & 25.0 & 24.3 & \\
France & 20.5 & 20.4 & 21.3 & & \\
Germany & 15.5 & 15.1 & 12.9 & 12.6 & 12.3 \\
Hungary & & & 22.8 & 22.7 & 21.4 \\
Ireland & 20.2 & 17.4 & 15.9 & 14.6 & \\
Italy & & & 15.5 & 15.4 & 15.2 \\
Korea & 4.5 & 4.5 & 4.4 & 4.5 & \\
The Netherlands & 15.1 & 12.9 & 12.6 & 12.4 & 12.2 \\
Portugal & 12.1 & & 15.5 & 15.2 & \\
Spain & 13.8 & 14.0 & 15.7 & 15.5 & 15.2 \\
Turkey & 7.7 & 7.9 & 9.3 & 9.1 & \\
UK & 21.6 & 19.5 & 12.9 & 12.7 & 12.6 \\
USA & 14.8 & 14.9 & 14.6 & 14.5 & 14.6 \\
Source & & & & &
\end{tabular}

Source: OECD Public Management Service (2001)

be an increasing commercial or business bias in the labor market and this is reflected in the changing enrolments by disciplines at the tertiary education level.

For the same high level of education, some skills are demanded in excess (e.g. by the IT or the biotechnology industry) while some others are in excess supply. Therefore, when a group is defined by the level of education, it is not surprising that over the past 20 years, earnings inequality within groups has increased.

\section{Skill supply and changes in wage-setting institutions}

On the supply side of the skilled labor market, two factors may help to explain larger within-group inequality.

First is the increasing labor force participation of women. Indeed, women tend to have less work experience and therefore, even if their skill is identical to males' one, their earnings are lower.

Second, immigration in the labor market increases the labor supply. It is also associated with increased casual employment, greater unemployment, competition, and weaker bargaining power of unions (Borjas et al., 1996). For the same level of education or skill, immigration tends to increase the wage segmentation of the associated skill labor market. Some people may argue that this second influence prevails only among low-skilled workers. However, as pointed out by Ramcharan (2001), the increased supply of unskilled labor due to massive immigration depresses the wages of the unskilled and increases the skill premium. This raises the comparative private return to education and investment in schooling especially for recent migrants. Moreover, the 
composition of immigration - between skilled and unskilled workers - is variable over time and also across countries. While many studies of the US labor market emphasize the labor market influence of immigration of low-skilled workers, immigration of skilled workers into that country has always been quite important. In many developed countries, the increase of the unemployment rate since the late 1970 s has led to a more restrictive immigration policy, especially against low-skilled workers, as in the Australian case, (see Table II) but it has not always been effective. However, immigration of skilled workers is not restricted and is sometimes even encouraged for some specific skills (such as skills consistent with IT).

Another explanation of rising wage inequality within the skilled group especially when measured at the local market level (McCall, 2000) - is provided by changes in the industrial relations front. Acemoglu (1997) demonstrates that increasing wage inequality - in the sense of between-group inequality - is more likely to occur in economies with less frictional labor markets. It turns out that mainly due to globalisation, the labor market in OECD countries is becoming more competitive (Tisdell and Svizzero, 2001). The case studies based on US data indicates that between-groups and within-group wage inequality moves in the same direction. Thus, inequality within-group increases with the degree of competition on the labor market.

Changes in wage-setting institutions, such as the declining influence of unions, is an additional explanation of increasing within-group wage dispersion. In the USA, the share of employed workers belonging to unions has eroded from a peak of 30 per cent through much of the 1950s and 1960s to about 15 per cent in 1995. Freeman (1993) estimated that the fall in unionisation

\begin{tabular}{lcccccr}
\hline & $\begin{array}{c}\text { Professional, } \\
\text { technical and } \\
\text { related workers }\end{array}$ & $\begin{array}{c}\text { Administrative } \\
\text { and managerial } \\
\text { workers }\end{array}$ & $\begin{array}{c}\text { Clerical and } \\
\text { related } \\
\text { workers }\end{array}$ & $\begin{array}{c}\text { Agriculture, } \\
\text { forestry workers, } \\
\text { fishermen }\end{array}$ & Others ${ }^{\text {a }}{ }^{\text {Year }}$ & Total \\
\hline 1990 & 23,811 & 6,900 & 23,748 & 1,534 & 0 & 54,993 \\
1991 & 47,624 & 13,574 & 38,438 & 1,960 & 0 & 101,296 \\
1992 & 47,587 & 13,329 & 38,865 & 1,777 & 0 & 98,558 \\
1993 & 43,556 & 13,069 & 32,856 & 1,738 & 0 & 91,219 \\
1994 & 48,648 & 15,604 & 30,880 & 1,854 & 0 & 101,293 \\
1995 & 53,857 & 18,732 & 38,010 & 1,936 & 0 & 112,535 \\
1996 & 54,699 & 20,411 & 38,711 & 2,087 & 0 & 115,908 \\
1997 & 57,665 & 17,253 & 36,850 & 2,106 & 0 & 113,874 \\
1998 & 63,151 & 13,993 & 40,602 & 2,733 & 0 & 120,479 \\
1999 & 70,569 & 15,973 & 46,050 & 2,776 & 0 & 135,368
\end{tabular}

Note: aSales workers, service workers, production workers, transport, equipment operators and labourers

Source: Department of Immigration and Multicultural Affairs
Table II. Inflows of employed immigrants by occupation in Australia, 1990-1999 
contributed to the 1980s rise in within-group earnings inequality, accounting for about 20 per cent of the overall increase of this inequality among men. It is well known that unions have always promoted centralised wage determination, reduced inequality in wages for workers having the same skills or the same occupational jobs. A usual objective of centralised bargaining is "equal pay for equal work", and thus it invariably imposes some uniformity of wages across workers for given tasks. The result is a reduction of the wage spread. Since the early 1980s, several OECD countries have shifted from centralised wage determination to the decentralisation of wage-setting via enterprise bargaining. This shift, directly linked to the decline of the bargaining strength of unions, comes from globalization and the general shift towards a market economy. Blau and Kahn (1996) considered that the decentralization of wage determination, i.e. the adoption of workplace relations acts or bargaining at the enterprise level, was the primary explanation for higher levels of residual inequality in the USA.

It is also important to note that, as stressed by Lindbeck and Snower (1996), the shift from centralised towards decentralised wage determination is not completely exogenous to agents' wishes. Indeed, the restructuring process of firms leading to more holistic organizations gives employers and employees growing incentives to choose decentralised bargaining arrangements. This stems from the fact that in holistic firms, different employees perform different sets of complementary tasks. Therefore, the marginal product of one employee's time at a particular task has no reason to be similar to the marginal product of another employee's time at that task. Holistic firms have an incentive to set wages in accordance with marginal products in people space and consequently to offer different workers different wages for the same task. This leads to increased wage dispersion, especially in countries where centralised bargaining had compressed the distribution of wages.

Finally, unemployment and casualization of work have led to a more flexible labor market and to its deinstitutionalization (McCall, 2000). The post-Second World War ideal of full-time, secure jobs with benefits and career mobility has disappeared. It has given way to an increase in part-time and temporary work and contracts, and insecure employment conditions. Furthermore, due to the existence of transaction costs, there has been an increase in overtime, especially among skilled workers. Therefore, with such a deinstitutionalized labor market, workers' willingness to make wage demands is reduced. Likewise, the range of wages offered by employers to similarly positioned workers is likely to widen.

Greater instability in earnings among people with the same characteristics then helps to explain partially, the increase in inequality. Gottschalk (1997) considers that one-third of the increase in within-group inequality reflects such increase in instability of earnings, the latter being clearly linked to the deinstitutionalization of the labour market. 


\section{Innate ability}

Since the 1970s, there has been greater access to education, more specifically to higher levels of education (see Table III). In most OECD countries, the amount of subsidies allocated to education has increased. Therefore, many skills that were in short supply are now less scarce. Since many people now have the same level and type of education, their rewards are not entirely based on their education level but also include a component for innate ability plus an allowance for length of work experience. In fact, the rewards of a worker have three parts. On the one hand, part of the reward is linked to human capital, i.e. their level of education and amount of work experience. On the other hand, another part of the reward - namely the rent - is associated with the natural capacity or innate ability of individuals.

Many factors help to explain how these innate abilities lead to the existence of inequality within-groups. As pointed out by Aghion et al. (1999), innate ability is in fact similar to skills that are unobservable at first sight. Unobserved skills, i.e. skills that are not directly measurable by education level and years on the job experience is a major factor helping to explain why within-group wage inequality emerges. For instance, Murnane et al. (1995), using data from two longitudinal surveys of American high school seniors showed that basic cognitive skills had a larger impact on wages for 24-year-old men and women in 1986 than in 1978.

Almost every person has innate ability but such ability is not necessarily complementary with any economic activity. Some innate abilities can be less valuable than others, depending on what are the leading industries. The complementarity of innate ability with the new technologies is a major factor explaining within-group income variation. Aghion et al. (1999) claim that the speed and nature of technical change interact with the dynamics of workers' knowledge to determine the returns to unmeasured skills. They also shape wage inequality within educational cohorts. In fact, when workers initially are equal in ability, within-group wage inequality may subsequently appear, since workers' adaptability to new technologies is variable (Aghion et al., 2000). First, the generality of the technology raises the ability of adaptable workers to transfer recently acquired knowledge to new machines. Second, this generality

\begin{tabular}{lcccc}
\hline Country & Secondary, 1980 & Secondary, 1997 & Tertiary, 1980 & Tertiary, 1997 \\
\hline Middle income & 52 & 69 & 10 & 12 \\
High income & 87 & $106^{\mathrm{a}}$ & 36 & 62 \\
Europe EMU & 81 & $108^{\mathrm{a}}$ & 25 & 49 \\
USA & 91 & 97 & 56 & 81 \\
UK & 84 & $129^{\mathrm{a}}$ & 19 & 52
\end{tabular}

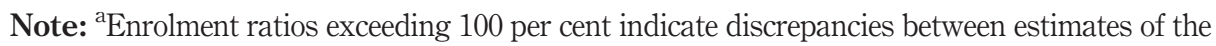
school age population and reported enrolment data.

Source: World Bank (2001)
Table III.

Participation in education (per cent of relevant age group) 
also reduces the cost of retooling old machines, and increases the demand for adaptable workers. Third, a rise in the speed of embodied technological progress raises the market premium to workers adaptable to the leading edge technology.

The globalisation process is also a part of the explanation. It is well known that, due to this process, the competitive pressure has increased on many markets, including the labor market. In globalised markets, top performers, i.e. workers having significant and large innate ability, are much more in demand than others. Indeed, as computing and telecommunications technology have advanced and facilitated the flow of information, and as transportation costs have fallen, increased mobility, competition to hire the best performers has risen, increasing their wages. Global competition has increased the rents payable to the most able workers. Therefore, the gap between their rewards and the rewards of workers having the same human capital level but less ability is escalating with the globalisation process.

This explanation is supported by the US Council of Economic Advisors (1998) which considers that "One provocative hypothesis offered to explain part of the increase in within-group inequality is the expansion of 'winner-take-all' markets". On these markets, top performers obtain greater rewards than do others whose ability is only slightly inferior. Many examples are provided in finance, law, sport. Since such markets have become more pervasive in the economy, the result is that the society is increasingly becoming a winner-take-all society. Such phenomenon is probably restricted to a small group of best performers.

Consequently, it does not adequately explain the growing income inequality within-groups. However, it is a good illustration of the existence of rents linked to natural capacity and market extension.

The hypothesis of a "winner-take-all society" is also supported by the introduction of new technologies. Indeed, technological change generates patterns similar to a "product life cycle" during which inequality among people are changing over time. Two different phases can be identified.

During the first period, i.e. just after the introduction of a new technology, the demand for appropriately skilled workers increases more rapidly than the supply. Therefore, the skill premium is increasing. Income inequality is increasing between skilled workers and unskilled workers and those skilled workers whose skills are not well suited or complementary to the new technology. In other words, gainers are those with specific skills, i.e. skills that are consistent with the new technology.

During the second phase or period of the cycle, a new sort of inequality appears. The skill premium is not shared by as many people as before. Two categories of people are now associated with the new technology industry. One category consists of "intermediate skilled workers" while the other one includes few people that are "highly skilled workers". In this second period, the 
economic conditions of workers in the former category show deterioration, i.e. their wages are no longer increasing, some are now considered as unskilled, and some others may lose their jobs. Two factors explain this shift. On the one hand, through education programs, the supply of skill adapted to new technology has increased. On the other hand, labor activities or programs are more and more embodied in products and machines. Therefore, the level of skills required to be able to use these products or machines is reduced.

What is now really needed is people with high skills and innate ability that are able to repair these machines and also to create new products and machines, in many cases embodying even more labor activities. For this second category of workers, the hypothesis of "winner-take-all" fits well. Their innate ability provides them with a rent, which in turns leads to widening income inequality within the skilled group and more generally to greater inequality among workers. Such inequalities cannot be easily reduced. Now the progressive income tax system puts higher pressure on higher incomes regardless of the level of the rent, the latter being difficult to assess. Moreover, even if a specific tax on rents could be levied, due to globalisation, the "highly skilled workers" would have an incentive to migrate to countries with lower fiscal pressure. Such a measure could damage a country adopting such measures since it will loose a large part of its élite. If economics are not to become locked into such inequality in the mature phase of the innovation cluster, it will be necessary to have new innovation clusters.

The restructuring process of Tayloristic firms to holistic ones presented by Lindbeck and Snower (1996) gives rise to a "cycle" similar to the one described previously. These authors demonstrate that the process leads the Lorenz curve becoming more curved, i.e. leads to more inequality. They also distinguish two periods. During the first period, the relative wage of versatile workers that are needed by holistic firms is increasing. In the second period, the wage of workers belonging to the Tayloristic firms is constant, since these firms have restructured their organizations. The holistic sector is still expanding while the non-versatile workers who have been laid off from the Tayloristic firms join an expanding pool of the jobless since they are unable to avail themselves of the new job opportunities.

\section{The education system and within-group inequality}

Several mechanisms may explain that to some extent, the education system is a factor which contributes to an increase of income inequality within-groups, especially within the group of skilled individuals.

First, the quality of educational institutions is much more heterogeneous now than before. Allowing people to have greater access to education has necessitated a larger number of educational institutions. Therefore, inequality has appeared among such institutions. Some older institutions are regarded as better while some new institutions are denigrated since they have a lower 
budget and less distinguished academic staff. Hence, often two persons having the same education level or even the same diploma but coming from different institutions are considered to be very different. Even these persons themselves often have this view, i.e. there is an endogenous autoselective process of discrimination.

Second, it is not true that equalising formal skills will equalise incomes. On the one hand, innate abilities are important even if they are complementary to the education level. However, the education system is not necessarily well tailored for identifying these abilities. The selection process in the education system is therefore not very efficient. On the other hand, increasing the access to education is not necessarily profitable. Of course, a threshold must remain, i.e. access to literacy should always exist. But, within a cohort of equal-age person, the return associated with investment in education usually has a large variance.

Some people do training and education in disciplines for which they believe they have talent, but do not. Some policies, based on affirmative action or positive discrimination, show that even if more support is provided to some people, the return may be lower than the one given by a less supported group of persons.

Given the current importance of innate ability, it seems that a higher degree of return on educational investment can be obtained by providing equal and greater access to education for people having the same degree but greater talent than by promoting equal access for anybody. However, even if such a policy is able to increase the return from the educational system, it will also increase the income inequality since the intellectual élite is advantaged more than the remaining population.

\section{Concluding comments}

Income inequality within groups accounts for a large part of the total increase in earnings inequality even if such inequality is not easily captured because the composition of groups is evolving and changing over time. This inequality is partly explained by specific rationales such as the greater access to higher level of education which has highlighted the role of innate ability. The general shift towards a market economy in OECD countries is also a specific explanation.

However, many explanations are common to income inequality between groups and income inequality within groups. Among them, innovation - more specifically the introduction of new technologies during the two previous decades - plays a central role. It has led to changes of the demand for skills and also to a greater variability of this demand, according to a cycle linking the demand for skills and the extent on which technical progress is embodied. It has also resulted in the reorganization of many firms - many have adopted a multiple-task scheme for each worker - leading to the decentralisation of wage determination which is more able to take into account innate ability of each 
worker. If the previous explanations of rising income inequality are common to inequality between groups and within groups, it should be noted that they act both through different channels and mechanisms. Consequently, the study of income inequality within groups per se is quite relevant since it provides complementary explanations and therefore helps to extend the explanation of the rise in overall earnings inequality in recent decades.

\section{Note}

1. The 90/50 is the ratio of the earnings of a worker at the 90th percentile (of the earnings distribution) to those of a worker at the 50th percentile (i.e. the median worker). The 50/10 ratio is defined in the same manner.

\section{References}

Acemoglu, D. (1997), "Matching heterogeneity and the evolution of income distribution", Journal of Economic Growth, Vol. 2, pp. 61-92.

Aghion, P. and Williamson, J.G. (1998), Growth, Inequality and Globalization, Cambridge University Press, Cambridge.

Aghion, P., Howitt, P. and Violante, G.L. (1999), Technology, Knowledge and Inequality, mimeo, Princeton University, Princeton.

Aghion, P., Howitt, P. and Violante, G.L. (2000), "General purpose technology and within-group inequality”, CEPR Discussion Paper No. 2474.

Atkinson, A. (1997), "Bringing income distribution in from the cold", Economic Journal, Vol. 107, pp. 291-321.

Atkinson, A. and Bourguignon, F. (1998), Introduction to Handbook of Income Distribution, North Holland, New York, NY.

Blau, F. and Kahn, L. (1996), "International differences in male wage inequality: institutions versus market forces", Journal of Political Economy, Vol. 104, pp. 791-837.

Borjas, G. (1994), "The economics of immigration”, Journal of Economic Literature, Vol. 32, pp. 1667-717.

Borjas, G.J., Freeman, R.B. and Katz, L.F. (1996), "Searching for the effect of immigration on the labor market", American Economic Review, Vol. 86, pp. 246-51.

Buchinsky, M. and Hunt, J. (1999), "Wage mobility in the United States", Review of Economics and Statistics, Vol. 131, pp. 351-68.

Disney, R. (2000), “Caught in a trap? Wage mobility in Great Britain: 1975-1994”, Economica, Vol. 67, pp. 477-97.

Freeman, R. (1993), "How much has deunionization contributed to the rise in male earnings inequality?", in Danziger, S. and Gottschalk, P. (Eds), Uneven Tides: Rising Inequality in America, Russell Sage Foundation, New York, NY, pp. 133-63.

Gottschalk, P. (1997), "Inequality, income growth, and mobility: the basic facts", Journal of Economic Perspectives, Vol. 11 No. 2, pp. 21-40.

Juhn, C., Murphy, K. and Pierce, B. (1993), "Wage inequality and the rise in returns to skill", Journal of Political Economy, Vol. 101, pp. 410-42.

Kuznets, S. (1955), "Economic growth and income inequality", American Economic Review, Vol. 45, pp. 1-28. 
Lawrence, R.Z. and Slaughter, M.J. (1993), "International trade and American wages in the 1980s: giant sucking sound or small hiccup?", Brookings Papers on Economic Activity, Vol. 2, pp. 161-210.

Lindbeck, A. and Snower, D.J. (1996), "Reorganisation of firms and labour-market inequality", American Economic Review, Vol. 86, pp. 315-21.

McCall, L. (2000), "Explaining levels of within-group wage inequality in US labor markets", Demography, Vol. 37 No. 4, pp. 415-30.

Murnane, R., Willet, J. and Levy, F. (1995), “The growing importance of cognitive skills in wage determination", Review of Economics and Statistics, Vol. 77 No. 2, pp. 251-66.

Ramcharan, R. (2001), "Globalization and human capital formation: theory and evidence from the US high school movement”, IMF Working Paper.

Sen, A.K. (1973), Oil Income Inequality, Oxford University Press, London.

Svizzero, S. and Tisdell, C.A. (2001), "Reconciling globalisation and technological change: growing income inequalities and remedial policies", Intereconomics. Review of European Economic Policy.

Tisdell, C.A. and Svizzero, S. (2001), "Globalization, social welfare, labor markets and fiscal competition”, Economic Theory, Applications and Issues Working Paper No. 5, School of Economics, University of Queensland, Brisbane.

US Council of Economic Advisors (1998), 1997 Economic Report of the President, Government Printings Office, Washington, DC.

Wood, A. (1998), "Globalisation and the rise in labour market inequalities", Economic Journal, Vol. 108, pp. 1463-82.

World Bank (2001), World Development Indicators, World Bank, Washington, DC. 